\title{
Paul Ricoeur and the Return of Humanism
}

\section{William Schweiker}

Over the course of some years I have written and lectured on Paul Ricoeur's thought, and I have also run graduate seminars and participated in other conferences and symposia dedicated to his work. And yet for all of that involvement, I would not consider myself a "Ricoeur scholar" in any technical sense of the term. Others at this conference, and especially Professor Charles Reagan, may rightly claim that title. I have sought to think with, sometimes against, and also, when possible, beyond Ricoeur's works with respect to questions that emerge at the intersection of hermeneutics, theology, and ethics. As a thinker and as a man, Ricoeur inspired many, many people. I draw on that inspiration today around the topic of how to formulate a viable kind of "humanism" for our time. Let me begin by introducing my topic and how I intend to address it. ${ }^{1}$

\section{The Question At Hand}

In this paper I want to think "after Ricoeur," and in two senses. I am trying, first, to address a question that is now emerging with its full force after Ricoeur's own life even if he foresaw its importance, namely, how to consider human existence in all its wild cultural and religious diversity but also its deep commonality in order to foster respect and betterment among peoples. Usually, this question is formulated in terms of universalism versus relativism, but I am addressing it with respect to conceptions of being human. ${ }^{2}$ Conflicts among peoples are ripping the world apart; it is time to address this challenge in every way 


\section{WILLIAM SCHWEIKER}

possible. Our situation thus poses anew and in a forceful way what Immanuel Kant — who was so dear to Ricoeur- thought was the fourth philosophical question. Recall that Kant insisted on three basic questions which, in fact, structure much of his critical philosophy and also Ricoeur's own thought: what can I know?, what ought I to do?, and what can I hope for? But there is a fourth question, Kant knew: what is man? Given the distinctiveness of peoples but also the continuities between human and non-human life, this fourth question forces itself upon reflective people with renewed vigor. It demands a new kind of humanism, I contend.

Second, I intend to explore this question of humanism by trying to think along with, to engage in a kind of "nach-denken" as the Germans might put it, and so to follow after Ricoeur's own pathway of thinking. This means a couple of things. As I will note in more detail shortly, throughout his career Ricoeur sought to articulate a specific kind of humanism, what he called the reality of the "third man" whose existence emerges in the productive interaction and struggle between Hellenistic and biblical sources within Western Civilization. This is a form of existence beyond those forces, and, so, perhaps a kind of nomadic way of life. I think we need third way thinking today too, but on a global scale. I will develop this from Christian sources, but I hope and believe that others will do something analogous from within their own traditions. And, second, Ricoeur always insisted that we are human, only human. The crucial dangers to human existence are, on the one hand, to conceive of our selves as somehow becoming more than human, to celebrate a kind of radical, heroic overcoming of our humanity, or, on the other hand, to fail to grasp the transcendent reach of human existence. I agree profoundly with Ricoeur on these matters, and, in fact, will try to advance the argument a bit further. What that entails for a renewed conception of humanism, what I will call "theological humanism," should become obvious in the course of my reflection.

With some sense of the task ahead, let me now turn to the first step in my inquiry and outline how Ricoeur's thoughts about the human effort to be, to exist, commits him to a form of humanism. That will be followed by a comparison of his thought with other positions he explicitly addressed on this topic, namely, Friedrich Nietzsche and Emmanuel Levinas. At the far end of the inquiry I will then be able to conclude with some reflections on theological humanism and its meaning for thinking "after Ricoeur." 


\section{RICOEUR AND THE RETURN OF HUMANISM}

\section{The Dispute About Humanism}

Humanism is often associated with the return to the classics by Renaissance thinkers as well as the celebration of human creativity. And there are, as we all know, various kinds of humanism, ranging from secular humanism to Christian and Jewish and other kinds of religious humanism. My task here is not to sort through all of those differences or even to engage the history of humanism. For present purposes it is enough to isolate some convictions that are widely shared among contemporary humanists despite whatever disagreements they may have. About shared convictions, Tzvetan Todorov has recently noted that humanists believe that "Freedom exists and that it is precious, but at the same time they appreciate the benefit of shared values, life with others, and a self that is held responsible for its action..." 3 Todorov formulates this outlook in terms of what he calls the autonomy of the I, the finality of the you, and the universality of the they. Put otherwise, the freedom of the self, the moral claim of others, and an inclusive moral community are basic humanistic values. Humanists also insist on human fallibility, and so humility in our appreciation of truth. Finally, humanists believe, in the words of the critic Edward Said, that "human history as made by human action and understood accordingly is the very ground of the humanities." "Most simply, for a humanist the purpose of thought and action is human flourishing, achieved by means of the distinctive human power to act and so to create history, whatever other non-human purposes and goods might obtain. These ideals reach a cultural apex in the West during the 18 and $19^{\text {th }}$ centuries even if they sparked criticism and rejection as well.

Given these beliefs, it is not surprising that we are now amid a widespread debate about the viability of humanism. In an age of global dynamics there is the possibility for expanded cosmopolitan or worldwide commitments, say to human rights, which challenge the tribalism of local loyalties and powers. Yet many people worry that humanistic ideals are themselves just the imposition of Western beliefs on other peoples and cultures. Further, the various forms of technology that characterize the global age are driven by anthropocentric values that endanger not only the natural environment but also myriad forms of non-human life. For many people, humanism cannot be reconciled with ecological sensibilities or concern for "animal rights." Additionally, as Ricoeur foresaw, there are new threats to the dignity and worth of the individual person. Individuals are being subsumed into the working 


\section{WILLIAM SCHWEIKER}

of massive, complex political, economic, and technological systems. Yet those systems, it would seem, can hardly be understood, let alone analyzed, if one clings to the traditional humanistic conviction that human beings and human beings alone "make" history. If we are to have a realistic grasp of the forces shaping the world, surely we must attend to the matrices of social power and the dynamics of complex systems freed from the humanistic bias for human agents. ${ }^{6}$ All of these developments characterize the "postmodern" or global age. They put pressure on humanistic thinkers to defend their ethical commitments as well to demonstrate the explanatory power of conceptions of history and society bound to human capacities for action.

The humanistic cast of Ricoeur's own thought has long been evident. It reaches from his earliest writings for the journal Esprit, influenced by the personalism of its founder Emmanuel Mounier, to his last lectures and texts. In contrast to those who reject humanism, Ricoeur held, like Todorov, Said and other contemporary neo-humanists, that all works of culture and society give expression, at least indirectly, to human freedom. The dignity and freedom of the human self, or the autonomy of the "I," is one of the dearest ideas to humanists. It is a conviction that Ricoeur tenaciously defended. In fact, he developed his position through sustained attention to human capability and also fallibility. As Ricoeur noted very late in his career, "I look at my work as an attempt to provide a survey of the capabilities, so to say, of the very I can. ... It can be read in terms of four verbs which the "I can" modifies: I can speak, I can do things, I can tell a story, and I can be imputed, an action can be imputed to me as its author."' The capacity for speech, action, historical understanding, and responsibility is predicated in complex ways of the "I" even as this "I" is only understandable in terms of these capabilities and their expressions. The effort to be, the I can, is basic, then, to representations in speech, action, narration, and the imputation of responsibility. Further, in his Gifford lectures, Oneself as Another, Ricoeur's trajectory of thought comes to its highest expression when he explores the various forms of capability with respect to "aiming at the good life with and for others in just institutions." That maxim from the "little ethics" of that text summarizes, in terms like Todorov's, the neo-humanistic contours of Ricoeur's thought. ${ }^{8}$ At the core of his far ranging corpus of work is, then, the belief that human beings are incomplete creatures striving for some kind of wholeness in our lives by means of cultural products and practices that endow life with meaning. 


\section{RICOEUR AND THE RETURN OF HUMANISM}

Attention to human capability and fallibility, and thus the priority of action to consciousness, required a significant shift in thinking. "Should we not say," Ricoeur wrote in one essay, "to exist is to act? Does not being, in the first instance, signify an act?" "Being," he continued, "is act before it is essence, because it is effort before it is representation or idea." The domain of representation and idea, the whole realm of meanings, thereby reveals and also conceals the human effort to be. Anyone who wants to understand human existence must interpret forms of representation in order to clarify the meaning of that struggle. Ricoeur himself engaged in a grand and intricate interpretation of things human in order to catch a glimpse of humanity in via, including the problem of evil that haunts the human adventure. ${ }^{10}$ Yet what does one mean by "the effort to be," its aim, and also the moral demand on our relations with each other?

Asking about the "effort to be" is a rather abstract way of putting a question that is actually woven into the texture of every human life. The raw struggle for life, the pitch of human wants and desires for fulfillment against the onslaught of age, death, and suffering, and likewise the pangs of love to embrace once more the beloved who has been lost testify to a Wille zur Leben, a will to life, an attestation of being, in human existence. To be or not to be is the question, Hamlet thought; the desire to be, the sense that it is good to be, is a primitive datum of human existence linked to the struggle to live. The decision to end life, the act of suicide, is then always an intentional act that must overcome the more primitive desire to live. Albert Camus thought that " $[t]$ here is but one truly serious philosophical problem, and that is suicide. Judging whether life is or is not worth living amounts to answering the fundamental questions of philosophy." "Yet that way of getting at the problem is in the order of critical judgment and philosophical reflection. More directly, more immediately, life makes a claim on us. While pessimism has been a seduction for some Western thinkers and always stalks the human psyche, most people most of the time love rather than hate life.

On the plane of actual existence arguably the basic question is whether it is good to be or not to be. This poses ethical and moral questions. Is the mere preservation of one's own life or the life of those dear to one the good to seek? What claim, if any, do others make upon my capacities, my power to act in the world? Which others matter? Is the aim of human capability just the increase of strength, the celebration of power and independence marked, say in some Greek 


\section{WILLIAM SCHWEIKER}

thinkers, by ideas of honor and glory and happiness (eudaimonia) rooted in the natural vitalities of existence? Is the norm for human action a command to care for the poor, the widow, and the stranger, a commandment of the God of the Bible, or is that command uttered simply and solely in the face of another suffering human being? How do these moral norms, whatever their content or origin, relate to the tenacity of the will to live? Must one extinguish the will to life in order to pay reverence to other forms of life? ${ }^{12}$

These are hardly abstract matters even if they can be formulated in abstract terms. The question of the relation between the effort to be, the will to life, and its proper norm or measure or aim presses on daily existence in so far as to be human is to live with others in shared institutions. Further, this question is at the center of current debates about humanism and Ricoeur's own response to competing philosophical positions. Put as a formula, Ricoeur's type of humanism arises from an attestation to being a self and yet also insists that we are "human, only human." Acknowledgment of the limits on human thought and action, limits rooted in our finitude and the reality of others, are necessary to a proper grasp of our existence. Only when human beings repent of all idolatry about their own power and knowledge is the dignity of human life manifest. In this respect, Ricoeur contends that theological discourse and religious convictions use concepts to denote limit experiences. They specify the finite condition of human existence while also indirectly configuring an attestation to being.

Later I want to press beyond Ricoeur's position and outline what I now call "theological humanism." The formula here is "human, truly human." 13 That is to say, I hope to bring to articulation a form of humanism distinctive in its features but conversant with others positions which, like Ricoeur, attend to the effort to be. That intention marks the horizon of this lecture and thereby will not be developed in great detail. ${ }^{14}$ On the way to that conclusion, it is necessary next to isolate the distinctive traits of Ricoeur's humanism in contrast to rival accounts of what it means to be human that also focus on the "effort to be."

\section{On Ricoeur's Humanism}

Ricoeur developed his own position through "detours" of interpretation and thereby engaging other thinkers. His ideas about humanism can best be seen in contrast to the Nietzschean formulation 


\section{RICOEUR AND THE RETURN OF HUMANISM}

of "human, all-too human" and also Emmanuel Levinas's humanism of the other, what I designate by the formula "human, othervise than human." ${ }^{15}$ Nietzsche, recall, sought to announce the coming man, the Übermensch, as a new form of existence. The daybreak of the Übermensch is the finality of human, all too human history. According to Levinas, the face of the other disrupts the drive to totality that is also the legacy of Western thought and life, especially under the dominance of Greek philosophy. The question of the limit and value of human power is thereby variously construed in these formulae. For Nietzsche, the willto-power finds its limit only in the coming Übermensch and so after the time of "man." With Levinas, the power of the self is decisively limited by the advent of the other, the command "Thou shall not Murder" uttered by the face of the other as if from Mt. Sinai.

According to Ricoeur, the limit to and value of human power is rooted in the attestation of oneself as anotherand the acknowledgement that we are human, only human. ${ }^{16}$ Against Nietzsche's paradigmatically "Greek" affirmation of human power where the vitalities of Will are to be ever increased, and Levinas's insistence on the finality of the other rooted in his sensibilities about Jewish law, Ricoeur explores the reality of the "third man," as he once called it. Neither dominated by forms of Greek thought, to which the Christian message was proclaimed, nor the circle of Hebraic life, from which the Gospel arose, this " "third man," Ricoeur notes, "this cultivated Christian, this believing Greek, is ourselves." ${ }^{\prime 17}$ This is not to say that Greek or Hebraic forms of humanism are impossible or invalid. Quite the contrary is the case. That is a reason to engage Nietzsche and Levinas. The point, rather, is that a Christian humanism, born from the tumultuous and yet exciting encounter of Greek and biblical modes of life, signifies a distinctive way of being in the world. It is the reality of the "third man" as a human possibility. Let me follow Ricoeur on this trajectory of thought.

Ricoeur asserted his own humanistic outlook in an early essay, “What does Humanism Mean?” In that essay, Ricoeur wrote:

Man is man when he knows that he is only man. The ancients called man a "mortal." This "remembrance of death" indicated in the very name of man introduces the reference to a limit at the very heart of the affirmation of man himself. When faced with the pretense of absolute knowledge, humanism is therefore the indication of an "only:" we are only men. No longer "human, all too 


\section{WILLIAM SCHWEIKER}

human:" this formula still shares in the intoxication of absolute knowledge; but "only human."18

Careful attention to this passage enables us to isolate the contours of Ricoeur's humanism in contrast to the Nietzschean formula "human, all too human" and Levinas's humanism of the other and its summary formula "human, otherwise than human."

In Ricoeur's early essays, and also much later in Oneself as Another, he explicitly sets his thought against Nietzsche. In the Gifford lectures Ricoeur identifies Nietzsche with the diminution of the self. Interestingly, in the early essay noted above the Nietzschean formula of "human, all too human" is associated with an excessive confidence in absolute knowledge. Against that excess, Ricoeur insisted on the limits to human knowledge, while in Oneself as Another he opposes Nietzsche's seeming reduction of the self to non-human causal forces. How can we explain the contradictory judgments about Nietzsche's thought and what is their significance for reading Ricoeur?

Ricoeur's point, on my understanding, is that humanism is inseparable from a perception of human beings as mortal, as deathbound. It is important to remember, as Tony Davies notes, the semantic density of the word "humanity." "The root-word is, quite literally, humble (bumilis), from the Latin bumus, earth or ground; hence bomo, earth-being, and bumanus, earthly, human." ${ }^{19}$ To be earth bound is, on Ricoeur's accounting, to be death-bound. There is a limit at the heart of the human project. Nietzsche's announcement of the coming of the Übermensch after a history dominated by the nihilism of human, all too human values aspires to a level of knowledge not possible for mortals. In other words, for Ricoeur humanism necessarily expresses itself in a philosophy of limits and the Nietzschean project strives to exceed that mortal limit. "Man" cannot be overcome or transcended. We are human, only human, Ricoeur insists. We have to forego any pretense to know or to achieve a form of existence beyond "man."

This initial response to the Nietzschean agenda only partially captures Ricoeur's thought as seen from the beginning to the end of his corpus. He always argued that at the heart of the human being is not simply the limit of mortality, but, much more, an attestation, a fundamental desire to be. Mortality is a limit but it is one within the affirmation of man himself. As we have already seen, the desire to be, attestation to the goodness of being, and not the Wille zur Macht, is what defines the human being. ${ }^{20}$ The limit on that affirmation of self 


\section{RICOEUR AND THE RETURN OF HUMANISM}

arising from within one's self is mortality, the awareness of death. While enduring the fact of mortality, there is nevertheless an attestation to the goodness of being "at the very heart of the affirmation of man himself." This affirmation opens another horizon to human time other than the fate of death. Through the power of the imagination, the desire to be reaches beyond mortality towards eternity in affirming its existence while also enacting its own limit. Nietzsche's attempt to reduce the human to the "will to power," no less than his hope in the coming Übermensch, must be brought to criticism. If the formula "human, all too human" betrays an aspiration to absolute knowledge of the coming "man" not possible for finite creatures, the reduction of human existence to the "will to power" fails to grasp the desire to be in its depth or scope. In the end, Nietzsche suffers inconsistency, exuding epistemic confidence bound to ontological reductionism. ${ }^{21}$ And that fact is, apparently, the reason for Ricoeur's seemingly contradictory judgments about Nietzsche's agenda.

What then is the "limit" on the human effort to be? How, if at all, is it related to the moral norms? Around this question revolved the encounter between Levinas and Ricoeur over many years. Levinas's claim, most boldly stated, is that the face of the other is the absolute limit on the drive to totality, that is, the drive of the self to subsume all being into the self. ${ }^{22}$ The other utters a command as if from the height of Mt. Sinai, the mountain of God: "Thou Shall Not Murder." For Levinas, the self is a servant, a hostage, of the other, and so infinitely responsible for the life of the other. The limit on the self, the assertion of the ethical intentionality of humanism, is the face of the other and not in the heart of self-affirmation. "I am," we might say for Levinas, because the other commands me to be responsible.

In this respect, the death of the other, and not my own death, discloses the unique singularity of human existence and designates the limit on human power. As Ricoeur notes about Levinas in Oneself as Another, "the face of the other raises itself before me, above me, it is not an appearance that I can include within the sphere of my representations. To be sure, the other appears, his face makes him appear, but the face is not a spectacle; it is a voice. The voice tells us, 'Thou shall not kill.' Each face is a Sinai that prohibits murder." ${ }^{23}$ Responsibility is an affirmation of the life of the other otherwise than the drive to totality arising from within the effort of the self. This is a humanism of the other. 


\section{WILLIAM SCHWEIKER}

It is at this juncture that Ricoeur sought to think through consistently the attestation to being. Again, there is a "limit at the very heart of the affirmation of man bimself.' What I find within myself is that through all the mediations of the desire to be, through labor, culture, and speech, I am also and always as another. There is an "otherness" at the core of the human self which, reciprocally construed, enables cojointly an affirmation of self and other. Ricoeur specified this otherness in a number of ways: the fact of embodied freedom; the relation of bios and logos in symbols; the dual horizon of human time and eternity configured in narratives; the mutual co-inherence in subjectivity between ipse and idem identity; and, the moral injunction to love others as oneself. The explanation of the details of those arguments spanning Ricoeur's corpus are beyond the scope of these reflections. ${ }^{24}$

How then does Ricoeur's argument differ from Levinas's position? The argument, if I understand him rightly, is that we are "only men," and that means, in distinction to Levinas, that human beings never escape, and in fact, will never escape, the tenacity of the effort to exist. An encounter between beings who are "only men" always risks the reduction of other to self or the servitude of self to other. The asymmetrical relation of actor and patient in human relations is the condition in which violence all too easily breaks forth. But the proper aim is a good life by means of responsibility for and with others within just institutions. In order rightly to appreciate Ricoeur's point here, one needs to see a subtle shift in his consideration of "the affirmation of man himself," a shift I bracketed when considering Ricoeur's response to the Nietzschean project.

Levinas sought to isolate the origin of self-consciousness either in the totalizing drive of the ego or in the encounter with the face of the other. Ricoeur did not try to establish the otherness of the other in terms of the origin of self-consciousness and thus the birthplace of the "I" and its representations. Having forsaken the search for a pristine origin of consciousness, he specified the trajectory or aim of responsible selfhood. If the defining fact of human being is not the cogito (the thinking "I" as the origin of representations), but, more simply, act and the desire to be, then human beings in affirming themselves at one and the same time affirm the being of others, even while there is the possibility of fault and violence rooted in the power to act. The responsible life is the enactment of mutual respect amid the aim of existence with and for others. This is why Ricoeur followed Kant and 


\section{RICOEUR AND THE RETURN OF HUMANISM}

insisted on reciprocal regard in formulating the moral law: treat humanity in oneself or another always as an end and not merely as a means to some other end. The categorical imperative is the deontological screen through which the search for the good life must necessarily move in light of the ever present possibility of violence. Any end that I seek, any conception of the good life, can only count as such if it meets the test of justice. To recall Todorov's phrase, Ricoeur insists on the finality of the "you," the moral claim of others. ${ }^{25}$ Yet this moral demand does not escape, indeed cannot escape, the "human, only human" character of the effort to be and also the lurking threat of violence.

It is important that the moral demand that limits any pursuit of the good life is found, according to Ricoeur, "at the very heart of the affirmation of man himself." Contrary to Levinas, the limit that constrains the wanton use of power in seeking the self's good is not heteronomous to the self, it is not from the demand of the other, but, rather, arises within self-affirmation, the attestation to the desire to be found in myself and all others. In a way decidedly different than Kant, on whom Ricoeur relies so heavily, the law-giving power of practical reason is not the heart of autonomy, of freedom. Mindful of the danger of violence, Ricoeur reformulates the meaning of freedom. "Ethical freedom," he writes, "is not a claim which proceeds from me and is opposed to any control; it is, rather, a demand which is addressed to me and which proceeds from the other: allow me to exist in front of you, as your equal." ${ }^{26}$ In a word, the limit is annunciated by the other to me, as Levinas rightly saw, but with respect to equal dignity, as Kant insisted. The moral demand is the prism though which any aim in life must pass if it is to be justified. The source of human dignity and its aim is neither the other as other (Levinas) nor the law-giving power of reason (Kant) but in the desire to be, the attestation to being, in self and other.

Stated most succinctly, Ricoeur's humanism articulates the norm for human power not as the increase of strength in order to overcome an all-too-human existence and thereby incarnate the Übermensch. The limit on power is not to be found in the ultimate perfection of power. The measure of the effort to be is likewise not a law announced in the face of the other that places the self on trial and instigates infinite responsibility for the other. From Ricoeur's perspective, these forms of thought share an unsustainable premise, namely, that by the increase of power or within the encounter with the other, the 


\section{WILLIAM SCHWEIKER}

human as mortal and yet self-affirming will be transcended. According to Ricoeur, we are "only men"; our form of life cannot and will not be overcome either in the future or in the face of the other.

The full complexity of the desire to be and its limit must then be grasped if we are to understand Ricoeur's brand of humanism and also isolate the point of departure for thinking beyond him. The desire to be bears within itself an irresolvable tension and perplexity, an aporia. To desire being is at once to affirm being but from within the lack of being; to desire is to affirm, to seek, within lack, and so marked with finitude. The limit on this desire arises from within mortality. It is why, as seen above, Ricoeur heralds "the remembrance of death." Yet if that claim alone was adequate for his brand of humanism, then privation, nothingness, sheer finitude would define the most basic contours of thought, and, further, being towards death, my own or that of the other, would be the necessary and sufficient conditions of valid thinking. Death is indeed necessary for valid reflection on human existence, but it is not sufficient. In facing death, as a finite end, there is also an attestation, an affirmation of life.

How might this aporia be represented so that through interpretation we can understand the full texture of the human project? In Ricoeur's judgment, death, as one temporal horizon of human existence, has its meaning in relation to the human capacity to imagine "eternity" as a horizon of meaning which exceeds finite limits. ${ }^{27}$ Eternity, likewise, has its meaning, for human beings, in its other: the orientation towards death that is the limit in the heart of self-affirmation. The fact that I can tell a story represents, configures, within the order of discourse both the limit (death) and the affirmation (eternity) that is at the heart of self-affirmation. Narratives render productive the aporia of human existence in time. ${ }^{28}$ The dual temporal structure of human being rendered productive in the capacity to narrate an account of one's life is, one must admit, an intuition, a grasp of (or being grasped by) a selfevident value.

Ricoeur insists that human existence is always open both to the ever-present possibility of death and yet in imagination, and so in hope, to a horizon of meaning that exceeds finitude and death. Cultural forms, works of art, and religious symbols provide configurations of human temporal existence through which one can grasp via careful interpretation the outlines of basic structures and dynamics of being human. And those same works open a vision of reality in which human beings can find their ownmost possibilities for life. Incomplete creatures 


\section{RICOEUR AND THE RETURN OF HUMANISM}

we are, but we are also beings who create meanings in order to discover the truth of our lives and thereby endow existence with significance. Ricoeur's humanism of limits, we can say, articulates these aporia of human being-in-the-world. The meaning of existence is attained through the interpretation of the manifold representations of the human effort to be. This brings me to the last step in my reflections and so the moving beyond Ricoeur's formula, "human, only human."

\section{Toward Theological Humanism}

The aporia of the desire to be, Ricoeur seems to be saying, imposes itself with the force of self-evidence and, when considered consistently, leads to a humanism of limits, the insight that "we are only men." This is where, as they say, the spade is turned. Ricoeur's account of the "third man" and with it the insight that we are human, only human, claims for itself the same level of plausibility and equal force of self-evidence as the $W$ ille zur Macht for Nietzscheans and the face of the other on Levinas's account. At this juncture in our reflections, a question naturally arises. Are these types of humanism exhaustive? Is there any other account that can make some claim to the force of selfevidence about the limit and value of the effort to be? The types, as we have seen, claim with Nietzsche, on one extreme, that the limit on human power is with respect to its destiny of self-overcoming, the emergence of a new form of human life after our buman, all too human existence. The philosopher seeks that new form of humanity. At the other end of the typology is Levinas's contention, appealing to the evidential power of the face of the other, that the limit on human power does not and cannot arise within the self's effort to be and thereby is, in this respect, human, otherwise than buman. And, finally, Ricoeur proposes a type of humanism which, we might say, mediates these extremes. It is a strictly philosophical account of the reality of the "third man" made possible in Christian faith. He locates a limit to the effort to be "at the very heart of the affirmation of man himself" and in the realization that we are buman, only buman specifies the norm of human power in terms of the demand to aim at the good life with and for others in just institutions. Are these the only options available to a humanist who seeks to unfold with the force of self-evidence the depth and limit on the effort to be? More pointedly, if one lifts the brackets Ricoeur places on theological thinking within his philosophy, is there another possibility for considering the reality of the "third man"? What 


\section{WILLIAM SCHWEIKER}

might that form of thinking contribute to the current debate about the task of humanism?

Another option is in fact possible; I designate it as "theological humanism." This too is a vision of life for the "third man," but it departs from Ricoeur, and so too Levinas and Nietzsche, insofar as the limit on human power is not my own morality, the death of the other, or the end of human, all too human history. The limit on human power, the measure of our effort to be, is the love of life, the depth of which is the love of the living God. The possibility of this measure, and so another form of humanism, arises from greater attention to an idea which I noted previously in these reflections and yet quickly suspended in order to engage Ricoeur's argument. The idea, recall, was that the hatred of life, articulated in a systematic pessimism or the challenge of wanton suicide, is not coequal, it does not bear the same evidential weight, as a primitive love of life. What if one attends to this love and its self-evident force in human existence?

To be sure, Ricoeur seemed to have grasped this point and that is why he insisted on the "affirmation of man himself." Yet, as we have seen, because he specifies this "affirmation" within the "effort to be," rather than with reference to the love of life, the limit of human power must be found in the other of attestation to power, namely, in death as the end of power and thus the end of the capacity for violence. The aporia that the affirmation of life bears its limit in mortality means that we are human, only human. Ricoeur's humanism, we might say, demarcates philosophically the space in which human existence can unfold within its own finite limits. He insists on this point, as we have seen, because the celebration of self-overcoming is finally beyond our capacities even as the command of the face of the other can never quell our self-affirmation. The question remains, however. Is mortality the "other" to the love of life that forms the limit to human power?

It is at this juncture that the narrative and symbolic resources of the biblical traditions enunciate another possibility on the plane of representations, which, I wager, can be redeemed philosophically in terms of their self-evidential power. Death may indeed form a limit to my power, so too the command not to kill the other or even the emergence of a new form of humanity. Yet none of those limits, rooted in mortality, limits the love of life by what exceeds human existence. They specify humanism just in terms of another human. The transcendence that marks the limit to human power is circumscribed by intra-human relations, what is sometimes called "lateral 


\section{RICOEUR AND THE RETURN OF HUMANISM}

transcendence" where God is conceived as a fiction (Nietzsche), a trace (Levinas) or within the mirror of scripture (Ricoeur). That is why, obviously, these are various kinds of humanism. Yet does it not also confront me with the force of self-evidence that the love of life is just that, a love of life that both exceeds and yet embraces human beings, including the human will to live ${ }^{29}$ How then to articulate this intuition? What representations can be used to articulate this love of life and its meaning for the limits on human power? Will this require a new type of humanism?

The biblical religions present in symbolic and narrative form the insight that the love of life finds its limit in the longing for the divine and thus intensifies human transcendence. In the love of God is disclosed a limit to the idolatry of any finite love, any elevation of self, other, or specific attachment to divine status. In the love of God, in other words, is represented the insight, the intuition, that we are human, truly human, only when our love for life embraces finite existence, our own and others, within a love of what exceeds the finite and yet endows mortal existence with distinctive dignity. As Ricoeur rightly saw, the love of life is the animating impulse of the effort to be. Yet when this love is embraced by a love of divine life, then, the biblical texts suggest, we are human, truly human. In fact, we might say, using Christian categories, that the "fall" into sin is precisely the regress from the truly human to being only human, to live limited by death rather than by the love of God. And in fact within the myth of the "fall," the account in Genesis, the connection is drawn between death and turning from God. In the fall, human beings are subjugated to the law of sin and death.

It is not surprising, then, that the biblical texts formulate the law of life, the proper limit on human power, in terms of the complex relation and ordering between the command to love God with one's whole heart, strength, and mind and one's neighbor as oneself. ${ }^{30}$ The great double love command specifies as a maxim of actions the limit of love on human capacity. The self-evident force of this maxim is found not in our mortality and violence (Ricoeur) or power (Nietzsche) or the vulnerability of the other (Levinas). It is found in that the love of finite life is also and always a longing for divine life. St. Augustine and many others rightly captured this insight by noting that in all loves what is co-loved is the divine, the living God. That insight must then be formulated not only as a type of humanism but also a kind of piety, 


\section{WILLIAM SCHWEIKER}

a religious longing. One can specify it as theological humanism whose basic formula is buman, truly buman.

That is not enough, however. Insofar as theological humanism is developed from Christian sources and with reference to the "third man" more needs to be said. One ought not to efface the "humanism" and the celebration of human vitalities through attention to the love of God. ${ }^{31}$ In this light, the claim of the Christian message is that the "God" who is loved in all acts of the love for life is the power of all life. Yet this divine life has been manifested in human time in the Christ, a power made perfect in the loving service of others. That insight enables the Christian imagination to intensify the law of freedom initially inscribed in biblical discourse in terms of the double love command. As St. Paul puts it at Galatians 5:13, "For you were called to freedom, brothers and sisters; only do not use your freedom as an opportunity for self-indulgence, but through love become slaves one to another. For the whole law is summed up in a single commandment, "You shall love your neighbor as yourself." Once life is seen "in Christ," then the double love command is intensified in the direction of love for the human other as the limit on human and even divine power. The contrast is no longer intra-human versus extra-human transcendence; there is an ingression of the love of God into the mutual love of neighbors. This requires that Christian theological humanism articulate itself through predicates borrowed from christological formulae: like Christ one is called to be human, truly human in the freedom of love. Yet this formula, I suggest, is not without the force of self-evidence; it is not merely a dogmatic assertion. The love of life, our own self-affirmation, the reciprocal claim of self and other, and a longing for the divine become articulate in the idea, the representation, of a Gospel of love. This is why the Gospel is the possibility of the "third man" who is neither slave nor free, Greek nor Jew, male nor female existing in a freedom other than the vitalities of nature or the giving of the law (Gal. 3:28). ${ }^{32}$

It is not clear that Ricoeur would reject my formulation of theological humanism for the "third man." However, it is obvious that he did not articulate his position in this way, owing, I suppose, to the division he drew between philosophical and theological reflection. My point is to note that within the reality of the "third man," that form of life marked as the believing Gentile, a type of humanism is possible wherein the limit on the effort to be is not simply the sting of mortality and the threat of violence to the other but much more the longing for 


\section{RICOEUR AND THE RETURN OF HUMANISM}

the divine. Once this longing, itself an attestation and a struggle, finds representation in the biblical witness, the limit on human power is the transformation of freedom in service and love to the other as oneself. Here is enacted, in a way contrary to Nietzsche, the overcoming, the perfection, of human existence. ${ }^{33}$ This limit, manifest in the Christ, is also the claim of the Christian conscience whose force of self-evidence is no less pointed than the law given at Sinai.

In closing, it might be asked of me why this revision in the humanistic agenda is needed for Christians, for the "third man," in our time. In my judgment, the development of theological humanism around the formula buman, truly buman, is required in order to accomplish a task that Ricoeur saw in the dawning of the global age and yet did not fully address. "The time in which we live," he wrote, "is one of planetary consciousness." And in this situation "[w] hat the theologian should rediscover here is that true Christian universalism which is a universalism of "intention" completely distinct from the universal "pretension" of the Christianity of the Constantinian Age." 34 Only when the humanism of the "third man" is formulated in order to respect and enhance the integrity of life rooted in the love of life and disciplined by the free service of others can it hope to speak to the needs and longings of an age riddled with endangerments to human and non-human life. One trusts that thinkers in other religious traditions will work out their own analogous kind of humanism. By isolating a new formula for humanism, I have thereby sought in this paper to think "after Ricoeur" by continuing further along that path he so brilliantly and faithfully sought to travel.

The University of Chicago

\section{Notes}

${ }^{1}$ I want to thank David E. Klemm for years of conversation about the subject matter of this essay and with whom I am currently writing a book on "theological humanism" (Blackwell Publishing, forthcoming). Portions of this essay have appeared previously in different form. See William Schweiker, "Paul Ricoeur and the Prospects of a New Humanism," in Reading Ricoeur, ed. David M. Kaplan (Albany: SUNY Press, 2007).

${ }^{2}$ On the current debate see Universalism vs. Relativism: Making Moral Judgments in a Changing, Pluralistic, and Threatening World, ed. Don Browning (New York: Rowman \& Littlefield, 2006). 


\section{WILLIAM SCHWEIKER}

${ }^{3}$ Tzvetan Todorov, Imperfect Garden: The Legacy of Humanism, trans. Carol Cosman (Princeton: Princeton University Press, 2002), 4.

${ }^{4}$ Edward W. Said, Humanism and Democratic Criticism (New York: Columbia University Press, 2004), 10.

${ }^{5}$ For the most ardent expression of this point see Peter Singer, Unsanctifying Human Life: Essays on Ethics (Oxford: Blackwell Publishing, 2002).

${ }^{6}$ One finds this argument made, on the one hand, by so-called systems theories, and, on the other, by theorists who explore patterns and circulation of power in societies. See, for example, Nikklas Luhmann, Theories of Distinction: Redescibing the Description of Modernity, ed. W. Rasch (Stanford: Stanford University Press, 2002) and Thomas E. Wartenberg, The Forms of Power: From Domination to Transformation (Philadelphia: Temple University Press, 1990).

${ }^{7}$ Paul Ricoeur, "Ethics and Human Capability: A Response," in Paul Ricoeur and Contemporary Moral Thought, eds. J. Wall, W. Schweiker, and W.D. Hall (New York: Routledge, 2002), 280.

${ }^{8}$ See Paul Ricoeur, Oneself as Another, trans. Kathleen Blamey (Chicago: The University of Chicago Press, 1992).

${ }^{9}$ Paul Ricoeur, "Nature and Freedom," in Political and Social Essays, eds. David Stewart and Joseph Bein (Athens, OH: Ohio University Press, 1974), 31-32.

${ }^{10}$ For an excellent account of Ricoeur's life and thought, see Chares E. Reagan, Paul Ricoeur: His Life and His Work (Chicago: The University of Chicago Press, 1996). A volume of responses to Ricoeur's work in a host of humanistic disciplines is Meanings in Texts and Actions: Questioning Paul Ricoeur, eds. David E. Klemm and William Schweiker (Charlottesville: University Press of Virginia, 1993). A conference held in 1999 on Ricoeur's work at The University of Chicago, including the closing address by Ricoeur about the scope of his philosophy, is published as Paul Ricoeur and Contemporary Moral Thought, eds. John Wall, William Schweiker, and W. David Hall (New York: Routledge, 2002). These volumes also include important bibliographies of Ricoeur's work and scholarship on his corpus.

${ }^{11}$ Albert Camus, "The Myth of Sisyphus," in The Myth of Sisyphus and Other Essays, trans. Justin O'Brien (New York: Vintage Books, 1991), 3. The question here is not the moral permissibility of suicide in extreme cases, but, rather, a question of principle. For a subtle discussion of these matters see James M. Gustafson, Ethics from a Theocentric Perspective, 2 vols. (Chicago: The University of Chicago Press, 1984, 1988). On this point also see John Lachs, In Love with Life: Reflections on the Joy of Living and Why We Hate to Die (Nashville: Vanderbilt University Press, 1998). It is instructive in this light also to consider again Leo Tolstoy's $A$ Confession, trans. A. Maude (Mineola: Dover Publications, 2005). 


\section{RICOEUR AND THE RETURN OF HUMANISM}

${ }^{12}$ This too is an option in Western ethics. For a crucial example, see Arthur Schopenhauer, The Basis of Morality, trans. A. B. Bullock (Mineola: Dover Publications, 2005). A similar argument is found in the works of Albert Schweitzer and his ethics for the reverence of life.

${ }^{13}$ On this see William Schweiker, Theological Ethics and Global Dynamics: In the Time of Many Worlds (Oxford: Blackwell Publishing, 2004). Also see the essays on theological humanism in Literature and Theology 18:3 (2004). The hermeneutical move that must be made, I judge, is from understanding the human "in the mirror of scripture," as Ricoeur emblematically puts it, to that of understanding existence "in Christ." On this see William Schweiker, "The Reason for Following: Moral Integrity and the Christological Summons," Faith and Philosopby 22:2 (2005): 173-198. Also see Robert P. Scharlemann, The Reason of Following: Christology and the Ecstatic I (Chicago: The University of Chicago Press, 1991).

${ }^{14}$ In terms of Protestant Christian thought, the most powerful expression was given by Paul Tillich when he spoke of "ecstatic humanism." See his Morality and Beyond, foreword by William Schweiker (Louisville: Westminster John Knox Press, 1995). For a brief examination of Tillich's project in our contemporary context see Max. L. Stackhouse, "Humanism After Tillich,” First Things 72 (April 1997): 24-28. For a discussion of Protestant and Roman Catholic humanism see R. William Franklin and Joseph M. Shaw, The Case for Christian Humanism (Grand Rapids: Eerdmans Publishing, 1991).

${ }^{15}$ Nietzsche's texts are well known, and Ricouer begins Oneself as Another with the contrast between Nietzsche and Descartes. Also see Emmanuel Levinas, Humanism of the Other, trans. Nidra Poller, intro. Richard A. Cohen (Chicago: The University of Illinois Press, 2003).

${ }^{16}$ Of course, any typology is fraught with dangers because it seeks to isolate the most basic contours of positions rather than to offer sustained analysis of any one position. And, likewise, a typology can appear to isolate merely logical rather than living options. Problems granted, it is still helpful to have some means to organize the contemporary intellectual scene and a typology is one way to do so.

${ }^{17}$ Ricoeur, "Faith and Culture," in Political and Social Essays, 126. Actually there is another problem here longstanding in Western thought that I cannot pause to explore, namely, the relation of "law" and "nature" in the guiding of human life.

${ }^{18}$ Ricoeur, "What Does Humanism Mean?" in Political and Social Essays, 86-87.

${ }^{19}$ Tony Davies, Humanism (New York: Routledge, 1997), 125

${ }^{20}$ While it is beyond the scope of this essay, this is the decisive reason why Ricoeur can endorse both Spinoza's idea of the conatus and also 


\section{WILLIAM SCHWEIKER}

Aristotelian teleological claims while rejecting the metaphysics of the will found in the pessimism of Schopenhauer or the vitalism of Nietzsche. See, for instance, his essay "Nature and Freedom," in Political and Social Essays, 2345 as well as the collection History and Truth, trans. Charles A. Kelbley (Evanston: Northwestern University Press, 1965).

${ }^{21}$ On can sense this contradiction build through the progression of essays in the famous Genealogy of Morals. See Friedrich Nietzsche, The Birth of Tragedy and the Genealogy of Morals, trans. Francis Golffing (New York: Doubleday Anchor Books, 1956).

${ }^{22}$ See Emmanuel Levinas, Totality and Infinity: An Essay on Exteriority, trans. A. Lingis (Pittsburgh: Duquesne University, 1969).

${ }^{23}$ Ricoeur, Oneself as Another, 336. I think the equation of killing and murder in this passage from Ricoeur is confusing. I do not see in Levinas's work a general, even universal, prohibition of "killing" but more precisely the categorical prohibition of murder. In Totality and Infinity Levinas wrote about ontology as a "philosophy of war," but it is not clear even there that overcoming "ontology" would mean the end of a conception of justified killing To be sure, Levinas always acknowledged the significance of pleasure in human life and also the origin of language and representations in the faceto-face encounter. He likewise argued that in the domain of politics, reciprocal obligations of justice mean that I can make a valid claim on others. Also see Emmanuel Levinas, Alterity and Transcendence, trans. Michael B. Smith (New York: Columbia University Press, 1999).

${ }^{24}$ I cannot pause to assess the adequacy of arguments by those who contend that his conception of selves "run the risk of reducing otherness to selfhood" and thereby falls to Levinas's criticism. See Richard Kearney, "'Narrative Imagination: Between Ethics and Politics," in Paul Ricoeur: The Hermeneutics of Action, ed. R. Kearney (London: Sage, 1996), p. 186. On this also see John Wall, Moral Creativity: Paul Ricoeur and the Poetics of Possibility (Oxford: Oxford University Press, 2005).

${ }^{25}$ There is of course consideration scholarship on the forms of Kant's categorical imperative and also its meaning. On this see Christine M. Korsegaard, The Sources of Normativity, ed. Onora O'Neill (Cambridge: Cambridge University Press, 1996). Also see William Schweiker, Responsibility and Christian Ethics (Cambridge: Cambridge University Press, 1995).

${ }^{26}$ Paul Ricoeur, "A Critique of B.F. Skinner's Beyond Freedom and Dignity," in Political and Social Essays, 63.

${ }^{27}$ One might note here that Ricoeur has retained and yet revised Martin Heidegger's understanding of time as the "meaning of being." For Ricoeur, "time" is indeed that "upon which" we project our own most possibilities, but those possibilities, rooted in the effort to be, exceeds being towards death. 


\section{RICOEUR AND THE RETURN OF HUMANISM}

${ }^{28}$ This is of course the force of Ricoeur's theory of narrative. See his Time and Narrative, 3 vols. trans. Kathleen McLaughlin and David Pellauer (Chicago: The University of Chicago Press, 1984-1988).

${ }^{29}$ For a position not unlike the one I am developing see Erazim Kohak, The Embers and the Stars: An Inquiry into the Moral Sense of Nature (Chicago: The University of Chicago Press, 1984).

${ }^{30}$ On this see William Schweiker, Power, Value and Conviction: Theological Ethics in the Postmodern Age (Cleveland: Pilgrim Press, 1998). For Ricoeur's reading of the command see his "Ethics and Theological Consideration on the Golden Rule," in Figuring the Sacred: Religion, Narrative, and Imagination, ed. Mark I. Wallace (Minneapolis: Fortress Press, 1995), 293-302.

${ }^{31} \mathrm{~A}$ common criticism by some neo-humanists, like Todorov, is that religious discourse, and especially Christian faith, is self-mutilating. That is, religious faith displaces proper concern for specifically human goods with a demand to love God in such a way as to demean human care. It should be obvious that my own formulation and Ricoeur's as well are not open to this charge.

${ }^{32}$ There is of course considerable interest now in Saint Paul, but this interest, as far as I can see, has not, sadly, been linked to any form of Christian humanism. See, for instance, Alain Badiou, Saint Paul: The Foundation of Universalism, trans. Ray Brassier (Stanford: Stanford University Press, 2003).

${ }^{33} \mathrm{On}$ this line of thinking, indebted to John Wesley, perfection in love is the proper aim and purpose of life.

${ }^{34}$ Paul Ricoeur, "From Nation to Humanity: Task of Christians," in Political and Social Essays, 134, 151. 